\title{
Phenomenon of effective interethnic interaction as an object of interdisciplinary research
}

\section{Феномен эффективного межэтнического взаимодействия как объект междисциплинарного исследования}

Received: May 5, 2021

Accepted: June 15, 2021

Written by:

Marina N. Kunovski ${ }^{87}$

https://orcid.org/0000-0002-5872-2052

SPIN: 7029-6172

Natalya V. Pomortseva ${ }^{88}$

https://orcid.org/0000-0003-4224-8138

SPIN: 5744-8264

\begin{abstract}
The article focuses on the analysis of "interethnic interaction" concept in the subject field of the humanities. The purpose of the study is the development of a theoretical model of effective interethnic interaction, whose projection to the various spheres of social relations, including educational and professional ones, will harmonize and make effective the communication of the various ethnic groups. A review of Russian and foreign literature on the above topic was carried out for research purposes. Multidimensional analysis of "interethnic interaction" concept was carried out using the method of comprehensive theoretical analysis of the phenomenon under study. As the result of the study, it was determined that interethnic interaction is one of the forms of interaction between social communities and individuals, during which the communicative process of ethnocultural and cultural-universal exchange of information at the level of personality, group or social institution takes place. As the research result, a model of interethnic interaction and its structure have been determined for the educational environment of an internationally oriented university. It was confirmed that the language of instruction is an integrating factor through which the preparation of the participants in the educational process, representatives of different ethnic groups, for effective inter-ethnic interaction is formed.
\end{abstract}

\begin{abstract}
Аннотация
Статья посвящена анализу понятия «межэтническое взаимодействие» в предметном поле гуманитарных наук. Целью является создание междисциплинарной теоретической модели эффективного межэтнического взаимодействия, проецирование которой на различные сферы социальных отношений, в том числе учебнопрофессиональную, позволит гармонизировать и сделать эффективной коммуникацию различных этносов. В целях исследования был проведен обзор российской и зарубежной литературы по заявленной проблематике. Многоаспектный анализ понятия «межэтническое взаимодействие» проведен с помощью метода комплексного теоретического анализа изучаемого явления. В результате исследования определено, что межэтническое взаимодействие представляет собой одну из форм взаимодействия социальных общностей и индивидов, в ходе которого осуществляется коммуникативный процесс обмена этнокультурной и общекультурной информацией с реализацией на разных уровнях (личности, группы или общественного института). По результатам исследования определена модель межэтнического взаимодействия и её структура для образовательной среды международно-ориентированного вуза. Установлено, что язык обучения является интегрирующим фактором, посредством которого формируется готовность участников
\end{abstract}

\footnotetext{
${ }^{87} \mathrm{PhD}$ in Philology, Assistant Professor, Head of Russian Language Department No. 2, the Russian Language and General Education Faculty, RUDN University, Russian Federation.

${ }^{88}$ Doctor of Pedagogy, Assistant Professor, Dean of the Russian Language and General Education Faculty, RUDN University, Russian
} Federation. 
Keywords: interethnic interaction, intercultural communication, academic environment, education, adaptation.

The publication was prepared within the framework of Research Project No. 17-29-09148 supported by the Russian Foundation for Basic Research.

\section{Introduction}

Due to the increasing globalization of business, educational and social contacts, the phenomenon of interethnic interaction is of interest in various fields of scientific knowledge: in linguistics, sociology, psychology, ethnopsychology, pedagogy, linguodidactics, and other sciences. With sufficient development of most aspects of interethnic interaction, however, there is currently no unified methodological approach to studying this phenomenon. Modern society is characterized by a constant increase in people's need for interethnic communication, which implies interethnic interaction, i.e. the contact of individuals belonging to different cultures and ethnic groups.

One of the tasks of the modern research paradigm is the search for an optimal model of effective interethnic interaction in various spheres of activity of modern society. Nowadays, due to the internationalization of education in the world, the subjects involved in the educational process of internationally oriented universities representatives of various ethnic groups - enter into interethnic interaction, accompanied by intensive adaptation to a non-native environment and training in a non-native language, which also increases the relevance of this study.

In the framework of the given research, the concept of interethnic interaction was considered in terms of different areas of scientific knowledge: linguistics, sociology, psychology, ethnopsychology, pedagogy, linguodidactics and other sciences. Interethnic interaction is defined as one of the forms of interaction between social communities and individuals, during which the communicative process of ethnocultural and cultural-universal exchange of information, symbols and knowledge, thoughts and feelings, social experience and morality of ethnic groups takes place. These relationships can be implemented at different levels (personality, group or social institution), in all possible areas. To perform the multicomponent analysis of образовательного процесса-представителей разных этносов к эффективному межэтническому взаимодействию.

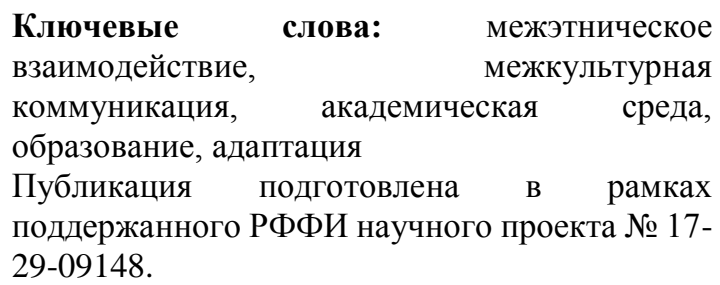

"interethnic interaction" concept, the following tasks were solved: consideration of the concept and related terms; determination of approaches to the definition of interethnic interaction; characteristics of "interethnic interaction" features from the point of view of various humanitarian sciences.

It was established that the theoretical model of interethnic interaction has a multicomponent structure, the projection of which, as one of the options, onto the organizational and content aspects of educational activities of educational institutions will harmonize the interaction of representatives of different ethnic groups in the academic environment. It will create the necessary pedagogical and organizationalmethodological conditions for increasing the efficiency of mastering the educational programs of internationally oriented universities. The result of the study will make it possible to create variable optimal models of effective interethnic interaction in various spheres of activity of modern society

\section{Materials and methods}

For research purposes, a detailed review of the studies by Russian and foreign scientists was made, which allows presenting interethnic interaction as a complex structure covering different aspects of interaction of ethnic groups in the multicultural world of social relations. To study the psychological factors of interethnic interaction, a potential of the most significant socio-psychological theories was used. From the standpoint of ethnopsychology, the systematization of provisions on intercultural communication of representatives of different ethnic groups is presented. From the standpoint of pedagogy and linguodidactics, studies are noted, in which interethnic interaction in the academic environment is considered through the dynamics of adaptation processes in a non-native linguoculture. The analysis of research in the 


\section{AMAZONDA}

field of linguodidactics made it possible to determine the importance of knowledge of the language of communication, the main cultural values of communication participants representatives of various ethnic groups.

The choice of research methodology is due to its complex nature. The multidimensional analysis of the concept of "interethnic interaction" was carried out using the method of a complex theoretical analysis of the phenomenon under study and made it possible to determine the intersubject field of the concept of "interethnic interaction" based on the achievements of sociology, ethnopsychology, ethnopedagogy, liguodidactics, and other sciences.

\section{Results and discussion}

The research focus of the humanities and social sciences is on various areas of interethnic interaction. Researchers describe its structural organization, identify dominant and secondary elements, factors, and characteristics. The dominant element of interethnic interaction in the works of many scientists is communication in various interpretations, language as a factor influencing the effectiveness of this kind of interaction, covering all spheres of human activity.

Pokrovskaya, integrating the philosophical, linguocultural, and psychological approaches, offers a conceptual model of interaction effectiveness at the intercultural and sociocultural levels. A "mentality-languagementality" triad is considered by Pokrovskaya as a complex systemic formation with certain linguocultural anthropological characteristics (Pokrovskaya, 2009). Khalturin proposes to consider a conceptual model of ethnocultural interaction, the structural basis of which is laid by "ethnic needs satisfied by social communities in various spheres of life" (Khalturin, 2015).

In the applied aspect, the problems of interethnic interaction are considered in combination with the issues of tolerance formation and in conjunction with the problems of adaptation of students from the polyethnic regions of Russia. Researchers come to the conclusion about the importance of ethnological education in the format of tolerance lessons, giving knowledge about the culture of different peoples, interethnic relations, introducing ethnocultural stereotypes. This seems to be especially important at the initial stage of education at a university (Belozerova, \& Shcheglova, 2010).
The British experience of forming interethnic relations by involving young people in public associations is described in the work by James Laurence (Laurence, 2020). He emphasizes that the improvement in interethnic relations among young people is primarily the result of an increase in the number of positive interethnic contacts and, accordingly, interethnic relations.

A large number of Russian and foreign studies are devoted to certain aspects of intercultural communication in education. The problem of the formation of a high level of interethnic communication among young people was considered by V. Andrianova (Andrianova, 2016). Intercultural dialogue in a philosophical context and other aspects of intercultural interaction were described and analyzed in the studies of G. Tulchinsky (Tulchinsky, 2014), who mentions the concept of "harmony in difference" as dynamic balance, realized in continuous dialogue. Building an effective dialogue is not a search for a compromise but a search for a broader context of common problems, which would allow the dialogue to be transformed into cooperation and partnership. The development of this approach could be a new understanding of multiculturalism and tolerance that presupposes not simply the recognition of the diversity of cultures, but a search for the basis of co-development and cooperation. Each culture, expressing a certain social experience, gives a certain life competence. The development of cultural experience does not cause a clash of cultures, but leads to the acquisition of additional life competence, and in its turn, to an increase in human and social capital.

Foreign studies consider issues related to the interaction and clash of cultures (Hanners, 1989; Popper, 1995; Schneider, \& Barsoux, 2003), the formation of intercultural communicative competence (Byram, 1997; Hampden-Turner, \& Trompenaars, 2000; Prechtl, \& Davidson-Lund, 2007; Spitzberg, 1989), problems of communication with strangers and the ways to overcome culture shock (Gudykunst, \& Kim, 1992; Marx, 1999). In his research, Pusch addresses the topic of intercultural learning from a historical perspective (Pusch, 2004).

The communicative experience of foreign students in US universities is studied in the work by Zimmermann (1995). She studied intercultural communication competence and adaptation of foreign students studying at the American campus. The results of the study show that adaptation to life in the country is most facilitated by direct communication between 
foreign students and Americans. According to Zimmerman, intercultural communication is not a "problem" to be solved - on the contrary, it is a phenomenon that needs to be carefully studied (Zimmerman, 1995).

The paper by Roiha and Sommier (2021) studies the attitude towards intercultural education among Dutch secondary school teachers. The results of the study show the importance of introducing intercultural education into the learning process, as well as the need to train teachers in order to provide tools for the implementation of intercultural education.

A number of works of recent decades are devoted to the issues of intercultural communication in the aspect of linguodidactics, in particular, the problems of teaching Russian as a foreign language in the linguistic environment and beyond. Scientists pay attention to the function of intercultural education in teaching tolerance to students (Klobukova, 2007). For successful psychological and social adaptation in a new cultural and linguistic space, it is important for a foreign student to master basic linguocultural concepts, which leads to the acceptance of the culture, values, and worldview of the people (native speakers) (Zyryanova et al., 2020).

However, the consideration of interethnic interaction within the framework of a single science (linguistics, linguodidactics, etc.) and only in one or two aspects does not ensure the completeness of the study and the possibility of large-scale generalizations for developing an effective model of interethnic interaction. The basis of interethnic interaction is language and culture, many phenomena with their own specifics, characteristics, development, and functioning features are involved, which led to the involvement of the methodological base of related sciences.

This study presents a systematic generalization of the results of the analysis of the interdisciplinary field "interethnic interaction", which includes a description of the achievements of modern science in the linguistic, psychological and social aspects.

The concept of "interethnic interaction" is based on two categories: "interaction" and "communication". Interaction is a category that reflects the very processes of influence of objects on each other, their mutual dependence, and the generation of one object by another, which is accompanied by the transfer of matter, information, and movement. In the modern philosophical theory, attention is paid to such a significant feature of communication as subjective interaction, as well as to the signoriented, symbolic nature of communication content, reflecting the richness of a certain human culture, which corresponds to the historical development of society at a certain time. One can agree with Kagan that "the process of communication is characterized by the presence of many forms, many levels at which it is carried out" (Kagan, 1996).

Currently, there are many theories, in the framework of which interethnic interaction is studied: the theory of functionalism, the theory of exchange, a phenomenological approach, the theory of acculturation, etc. (Asanova, 2008). According to the theory of exchange, interethnic interaction and intercultural communication are rationally explained, through the balance of benefits and non-benefits of spreading a standard culture or preserving diversity. The functional theory characterizes the interconnection of the language system elements as functionally additional, bearing in mind that language subsystems used by a certain society are distributed over all spheres of use, communicative situations, and social functions (Asanova, 2008).

The communicative behavior features of representatives of certain cultures depend on the type of culture to which the participants in communication belong. Hall divides all cultures into low-context (with an emphasis on verbal communication) and high-context ones (with an emphasis on non-verbal communication contributing to the correct interpretation of verbal signals and on additional information time, place, and other factors) (Hall \& Hall, 1990).

In this regard, when studying the phenomenon of interethnic interaction, the concept of "ethnic identity" becomes important, which implies the result of an individual's awareness of his or her ethnicity, identification with representatives of his or her ethnic group, and isolation from other ethnic groups. The essential characteristic of this identity consists of certain objective (language, culture, traditions, religion, etc.) and subjective factors (interests, orientations, preferences).

In linguistic research, interethnic interaction is studied in two main directions: interlanguage interaction, dialogue of cultures (an aspect of cultural linguistics), which entails the concept of "intercultural communication". According to Trager and Hall, intercultural communication has 


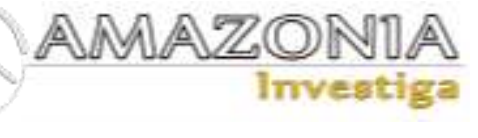

a goal for which a person should strive in his/her desire to adapt to the world around him/her as effectively as possible (Trager, \& Hall, 1954). The philosopher Kurlov supported the opinion of these authors, calling intercultural communication an ideal communication model, the main characteristic of which is the primacy of communication, especially interpersonal communication (Kurlov, 2002).

The intensity and effectiveness of intercultural communication are significant factors in the life of an individual in society or in a different society, as well as the factors of its development through participation in intercultural communication. According to Spitzberg and Cupach, this is largely facilitated by intercultural knowledge, which is necessary, but not determining in assessing the effectiveness of intercultural communication (Spitzberg, \& Cupach, 1984). The characteristics of this concept are extensive and depend on cultural differences, territorial residence, lifestyle, traditions, language communication.

Intercultural communication is a special area of human relations that unites communication and culture and involves the joint activities of people from different cultures. Many foreign researchers define intercultural communication as the interaction between representatives of different cultures, during which communicants transfer their experience, knowledge, and value system, emphasizing the essence of both their own and foreign culture (Kripon, 2006). Comparative study of foreign cultures and comparison with the native culture avoids further communication problems and minimizes possible culture shock.

In psychological research, to study the psychological factors of interethnic interactions, they use the potential of the most significant socio-psychological theories, which make it possible to study the nature of a person entering complex ethnocultural formations. In some psychological studies, a person is considered as a set of social roles and individual characteristics, in others - a person is assessed as a system of socially significant characteristics and properties integrated in a person that arose in the direct or indirect interaction of a person with other people.

The analysis of the nature and content of interethnic communications is impossible without taking into account the theory of attitudes (Smith, Allport). For this study, it is important to understand the attitude as a socially grounded relationship to a phenomenon, a person, an object - or rather, the narrower concepts of interethnic and ethnic attitudes used in the framework of ethnosociology. Traditionally, ethnic attitudes are determined by awareness, assessment of a person who identifies him/herself with a particular ethnic group. Interethnic attitudes are determined by entering into various kinds of communication with representatives of other ethnic formations.

To analyze the nature of interethnic communications, it is important to consider the concept of "ethnic stereotype" as a stable, historically corrected representation at the level of public consciousness about an ethnic group through the characteristics of their behavioral, physical, and mental manifestations. They are conditionally differentiated into heterostereotypes (assessment by representatives of one ethnos or ethnic group of representatives (or an ethnos as a whole) of another nationality) and autostereotypes (assessment of oneself as part of a certain ethnic group).

The component structure of ethnic stereotypes is made up of two types of knowledge and perceptions. The first type includes ideas and judgments assessing the external appearance of representatives of other ethnic groups, the history of the people, traditions and customs, lifestyle peculiarities, etc. The second type of ideas and knowledge in stereotypes reflects the assessment of communicative properties, moral qualities of representatives of this ethnic group. In this regard, ethnic stereotypes are assessed in psychology as determining in the system of interethnic communications.

Ethnic stereotypes are assessed in a different way in the framework of ethnosociological research. The first difference is associated with the fact that the basis of ethnic stereotypes is a complex of the traditional culture of the ethnos. This is a stable foundation that allows making stable assessments and creating a stable system of signs and symbols about this ethnic community. "Ethnocultural stereotypes are a generalized idea of typical features, characteristics of a certain people" (Rosenko et al., 2007, p. 120). The second difference is associated with the need to differentiate the object and the situational space in which this object is now located.

During the analysis conducted within the framework of this study, attention was also paid to the phenomena of ethnic consolidation and national self-awareness. Drobizheva proposes to consider the structure of self-awareness in general and national self-awareness in particular horizontally (this perspective of self-awareness 
includes the feeling of belonging to a particular ethnic group, this is the nature of ethnic identity) and vertically (this perspective of self-awareness reveals deeper stereotypical characteristics, more fundamental - psychological and historicalcultural - foundations) (Drobizheva, 2003). The growth of national self-awareness can be determined by two trends: 1) an increase in the identification belonging to a certain ethnos, a feeling of one's own involvement in this group, a desire to develop and stay in this national space; 2) a feeling of one's own belonging to a certain ethnos due to the non-recognition of significance and objectivity of existence of other ethnoses, ignoring their interests and determining one's own exclusivity (Drobizheva, 2003).

In the studies carried out within the framework of social psychology and ethnopsychology, when considering the problem of interethnic interaction, the emphasis is placed on the development of the ethnos, which is considered one of the participants in the analyzed process. A single ethnos as a complex self-developing system in its existence goes through a number of stages, each of which has a different level of potential conflictogenity (i.e. the ability of an ethnos to initiate conflicts in relation to other ethnic communities). It should be noted that an important circumstance in the field of interethnic communication is the mutual cultural adaptation and integration of ethnosocial subjects (Goncharova, 2017).

A separate segment of the communicative space is the conflict space, which is the area of those interaction options that are unambiguously interpreted as aggressive and offensive (for example, the use of derogatory ethnonyms, ridicule of ethnocultural prohibitions and prescriptions, etc.). By the beginning of the 21st century, the clash of cultures has become exponential in nature, including due to the development of global transport systems and information technologies. They allow familiarizing with a foreign culture and an unusual worldview not in their indirectly adapted version, but in an ordinary form: in the form of real-life events and related experiences, expectations, fears. All this led to the creation of technical prerequisites for the formation of not just an interethnic, but global communication space.

During the implementation of interethnic interaction, a person's attitude towards another person is revealed as to a subject with his or her own world. In interethnic relations, systemic contradictions can often arise (Samrailova,
2009), which can lead in the future to a change in the group and individual characteristics that interact with one another. Currently, interethnic communication is being implemented against the background of the growth of social, economic, and political instability in society, which inevitably leads to the emergence of conflicts on interethnic and cross-national grounds.

An alternative to interethnic confrontation can be such communicative behavior of representatives of different cultures, which implies openness towards the interlocutor, the creation of a positive attitude and an atmosphere of equality, and this, in turn, will allow achieving mutual understanding and agreement in interpersonal contacts. In this regard, in a multicultural educational environment, one of the key concepts is the concept of interethnic tolerance.

From the standpoint of linguodidactics, tolerance is understood as tolerance for other people's opinions, ideas, concepts, unusual forms of expression of any meaning in a language, rules of behavior that are not accepted in the native culture, etc. According to Klobukova, this makes it necessary to formulate the task of forming foreign students' tolerant consciousness as a special goal of teaching Russian as a foreign language (Klobukova, 2007). This goal meets both students' personal interests and objective social needs, since modern society, where the mixing of cultures is especially intense, is interested in achieving maximum mutual understanding, both between its individual members and between different social groups.

In modern research on pedagogy and linguodidactics, interethnic interaction in the academic environment is considered through integration with the dynamics of adaptation processes in a non-native linguoculture. For example, Krotova determined the influence of ethnospecific factors on the process of adaptation of Arab students to learning and linguistic existence in the Russian linguocultural environment, substantiated the need to take these factors into account when choosing forms of educational interaction between a teacher and a foreign student (Krotova, 2015). Pomortseva defined linguistic and cultural adaptation "as a process of entering the value-semantic field of a different sociocultural environment through learning the Russian language, studying Russian culture and cultural creativity" (Pomortseva, 2010). 


\section{Conclusions}

The interdisciplinary analysis of the concept of "interethnic interaction" allows concluding that interethnic interaction is one of the forms of interaction between social communities and individuals, during which the communicative process of exchanging ethnocultural and cultureuniversal information, symbols and knowledge, thoughts and feelings, social and moral experience between ethnic groups is carried out. These relationships can be implemented at different levels (personality, group, or social institution), in all possible spheres. In particular, in the educational environment of an internationally oriented university, interethnic interaction is defined as a spontaneous and specially organized communication of participants in the educational process representatives of different ethnic groups in the educational, social-household, educationalprofessional, socio-cultural spheres of communication, structured according to the following levels: "student - teacher", "student student, representative of another ethnos", "student - educational environment", "student multinational educational team", "student environment". The language of instruction is an integrating factor through which the readiness of participants in the educational process, representatives of different ethnic groups, is formed for effective interethnic interaction. The theoretical model of interethnic interaction has a multicomponent structure, the projection of which, in particular, as one of the options, on the organizational and substantive aspects of educational activities of educational institutions will harmonize the interaction of representatives of different ethnic groups in the academic environment, create the necessary pedagogical and organizational-methodological conditions to increase the efficiency of mastery of educational programs in internationally oriented universities. The research result will make it possible to develop optimal models of effective interethnic interaction in various spheres of activity of modern society.

\section{References}

Andrianova, V.A. (2016). Language and intercultural communication: interaction of cultures through tourism. Tourism Industry: Opportunities, Priorities, Problems and Prospects, 9(2), 217-223.

Asanova, E.S. (2008). Ethnocultural Factors of Interethnic Interaction. Young voices in science, Issue 12, Maikop: Adyghe State University.
Belozerova, M.V., \& Shcheglova, M.S. (2010). Tolerance and problems of intercultural interaction in the student environment (according to the results of a sociological survey of students studying at Kemerovo State Institute of Culture from among indigenous peoples. Bulletin of Kemerovo State Institute of Culture and Arts. Journal of Theoretical and Applied Research Journal, 13, 90-98.

Byram, M. (1997). Teaching and Assessing Intercultural Communicative Competence. Clevedon: Multilingual Matters.

Drobizheva, L.N. (2003). Social Problems of Interethnic Relations in Post-Soviet Russia. Moscow: Center for Human Values.

Goncharova, N.I. (2017). Conflict nature of interethnic communications: socio-cultural and legal context. National cultures in communication. In Collection of Scientific Articles Based on the Materials of the II International Scientific and Practical Conference (pp. 121-130). Belarusian State University, Minsk,

https:/elib.bsu.by/handle/123456789/188939

Gudykunst, W., \& Kim, Y. (1992). Communicating with Strangers. New York: McGraw-Hill.

Hall, E.T., \& Hall, M.R. (1990). Understanding Cultural Differences: Germans, French and Americans. Yarmouth, ME: Intercultural Press. Hampden-Turner, C., \& Trompenaars, F. (2000). Building Cross-Cultural Competence: How to Create Wealth from Conflicting Values. Chichester: John Wiley.

Hanners, U. (1989). Notes on global ecumene. Public Culture, 1, 65-75.

Kagan, M.S. (1996). Philosophy of Culture. St. Petersburg: Petropolis.

Khalturin, A.N. (2015). Conceptual Model of Ethnocultural Interaction. Historical, Philosophical, Political and Law Sciences, Culturology and Study of Art. Issues of Theory and Practice, 10(60), Part II, 196-198

Klobukova, L.P. (2007). Methodical aspects of formation of tolerant consciousness in students when teaching Russian as a foreign language. RUDN Journal of Language Education and Translingual Practices, 2, 55-59.

Kripon, N.S. (2006). Development of Value Orientations of University Students in Intercultural Communication (Ph.D. Thesis). Nosov Magnitogorsk State Technical University, Magnitogorsk.

Krotova, T.A. (2015). Ethno-oriented system of linguocultural adaptation of Arab students in the practice of RFL teaching (Ph.D. Thesis Abstract). RUDN University, Moscow.

Kurlov, A.B. (2002). Fundamentals of Communication Theory. Ufa: Bashkir State 
University,

https://search.rsl.ru/ru/record/01000985869.

Laurence, J. (2020). Cohesion through participation? Youth engagement, interethnic attitudes, and pathways of positive and negative intergroup contact among adolescents: a quasiexperimental field study. Journal of Ethnic and Migration Studies, 46(13), 2700-2722, DOI: 10.1080/1369183X.2019.1700787.

Marx, E. (1999). Breaking through Culture Shock. London: Nicholas Brealey.

Pokrovskaya, E.M. (2009). The Problem of Effective Intercultural and Socio-cultural Linguistic Interaction in the Modern World (Ph.D. Thesis Abstract). Tomsk State University of Control Systems and Radioelectronics, Tomsk.

Pomortseva, N.V. (2010). Pedagogical System of Linguocultural Adaptation of Foreign Students in the Process of Teaching the Russian Language (Ph.D. Thesis). RUDN University, Moscow.

Popper, K. (1995). On culture clash. In K. Popper, In Search of a Better World: Lectures and Essays from Thirty Years (pp. 201-216). London: Routledge, https://www.taylorfrancis.com/books/mono/10.4 324/9780203535486/search-better-world-karlpopper

Prechtl, E., \& Davidson-Lund, A. (2007). Intercultural competence and assessment: Perspectives from the INCA project. In $\mathrm{H}$. Kotthoff, \& H. Spencer-Oatey (Eds.), Handbook of Intercultural Communication (pp. 467-490). Berlin: Mouton de Gruyter.

Pusch, M.D. (2004). Intercultural training in historical perspective. In D. Landis (Ed.), Handbook of Intercultural Training (pp. 13-36). Thousand Oaks, California: Sage Publications. Roiha, A., \& Sommier, M. (2021). Exploring teachers' perceptions and practices of intercultural education in an international school. Intercultural Education. DOI: 10.1080/14675986.2021.1893986
Rosenko, M.N., Boronoev, A.O., \& Doronchenkov, A.I. (2007). Nations and Ethnicities in the Modern World: Glossary. St. Petersburg:

https://www.iprbookshop.ru/20324

Samrailova, E.K. (2009). System-Forming Contradictions in Interethnic Relations. Moscow:

https://search.rsl.ru/ru/record/01003091520

Schneider, S.C., \& Barsoux, J.-L. (2003). Managing Across Cultures. London: Prentice Hall.

Spitzberg, B., \& Cupach, W. (1984). Interpersonal Communication Competence. Beverly Hills, CA: Sage.

Spitzberg, B.H. (1989). Issues in the development of a theory of interpersonal competence in the intercultural context. International Journal of Intercultural Relations, 13, 241-268.

Trager, D., \& Hall, E. (1954). Culture as Communication: A Model and Analysis. New York: Explorations: Studies in Culture and Communication, 3, 137-149.

Tulchinsky, G.L. (2014). Philosophy as a Paradigm of Intercultural Dialogue. In E. Demenchonok (Ed.), Intercultural Dialogue: In Search of Harmony in Diversity (pp. 148-154). Newcastle upon Tyne, UK: Cambridge Scholars Publ.,

http://phisci.ru/files/issues/2015/11/RJPS_201511_Tulchinsky.pdf

Zimmermann, S. (1995). Perceptions of intercultural communication competence and international student adaptation to an American campus. Communication Education, 44(4), 321-335. DOI: 10.1080/03634529509379022

Zyryanova, S., Chesnokova, N., Shtanko, M., \& Dudareva, M. (2020). The link between language and culture on the lessons of Russian as a foreign language. Amazonia Investiga, 9(28), 421-426. DOI:

https://doi.org/10.34069/AI/2020.28.04.47. 